\title{
Ejen "pétrir" : produire de la nourriture - et du sens?
}

\section{Françoise Abel}

\section{(2) OpenEdition}

\section{Journals}

Édition électronique

URL : https://journals.openedition.org/tc/1004

DOI : $10.4000 /$ tc. 1004

ISSN : 1952-420X

Éditeur

Éditions de l'EHESS

\section{Édition imprimée}

Date de publication : 1 juin 1984

ISSN : 0248-6016

\section{Référence électronique}

Françoise Abel, « Ejen "pétrir" : produire de la nourriture - et du sens ? », Techniques \& Culture [En ligne], 3 | 1984, mis en ligne le 26 janvier 2006, consulté le 29 septembre 2022. URL : http:// journals.openedition.org/tc/1004; DOI : https://doi.org/10.4000/tc.1004

Ce document a été généré automatiquement le 29 septembre 2022.

Tous droits réservés 


\section{Ejen "pétrir" : produire de la nourriture - et du sens ?}

Françoise Abel 